\title{
Effect of Respiratory Relaxation Techniques on Pain Adaptation in Maternity Mothers at Rsu Royal Prima in 2020
}

\author{
Wang Chunxiang ${ }^{1}$, Florenly ${ }^{2}$, Liena $^{3}$, Dewi Riastawaty Purba ${ }^{4}$ \\ ${ }^{1,2,3,4}$ Departement of Medicine, Faculty of Medicine, Universitas Prima Indonesia \\ liena@unprimdn.ac.id
}

\begin{abstract}
Every year an estimated 529,000 women die as a result of complications arising from pregnancy and childbirth. Labor pain is a physiological condition, an unpleasant feeling that occurs during labor. Nonpharmacological pain management can increase satisfaction during labor because the patient can control his feelings and strength, one of which is the texture of respiratory relaxation. The purpose of this study was to find out the effect of respiratory relaxation techniques on pain adaptation in maternity mothers. This type of research is descriptively correlational, using the One Group Pretest-Postest approach. Location in RSU Royal Prima Jalan Ayahanda Number 68A, Sei Putih Tengah, Medan Petisah, North Sumatra, september - November 2020. The population of 43 people, determining the number of samples with the formula slovin, so that the sample was obtained as many as 30 people. The data analysis used is a normality test using the Shapiro Wilk test, because the number of samples is <50. Bivariate analysis of the data is distributed normally using an at-dependent test (paired t-test), while if the data is not distributed normally using the Wilcoxon Signed Rank Test, with a meaningful limit of $<0.05$. The results of the study score change in the level of pain Wilcoxon test results at the time of the pre-test test the result of a mean value of 3,466, at the time of the post-test test the mean value of 3,166. So the result of the value $Z=-2,714$ then $p$-value as much as $0.007<0.05$ so that it is concluded ho rejected and Ha received, which means there is an effect of giving respiratory relaxation techniques to changes in pain in maternity mothers when-I at RSU Royal Prima in 2020.
\end{abstract}

Keywords: technique; relaxation; breathing; pain; childbirth

\section{Introduction}

Labor is a uterine contraction as it can cause cervical dilation and thinning all the time, and can create a strong urge as it can give birth to a fetus from the road, a birth that can fight the resistance of the pelvic bone structure, soft tissue resistance and muscle (Sumarni and Yasin 2016). One of the indicators in determining the degree of health of a nation with high maternal and infant mortality rates. Maternal Mortality Rate (AKI) is based on the risk of maternal death related to childbirth, childbirth, obstetric care, pregnancy complications, and at the time of postpartum (Aeni 2011). Every year an estimated 529,000 women die as a result of complications arising from pregnancy and childbirth, so there is an estimated maternal mortality rate of 400 per 100,000 live births (Respati, Sulistyowati, and Nababan 2019).

Labor pain is a physiological condition, an unpleasant feeling that occurs during labor. Labor pain begins to arise in labor when I latent phase and active phase. The longer the pain felt will get stronger, the peak of pain occurs in the active phase, where the complete opening is up to $10 \mathrm{~cm}$. The intensity of pain during labor will affect the psychological condition of the mother, the process of delivery, and the well-being of the fetus (Rejeki 2013). Some studies show that in primitive societies, labor is long and 
painful, while people who have advanced $7-14 \%$ of maternity without pain and most (90\%) of labor accompanied by pain. The high perception of pain felt by maternity mothers so that most of them do not focus on the birth of their babies, instead, they focus more on the pain of childbirth that they feel (Widiawati and Legiati 2017). Feelings of fear, and anxiety, at the time of delivery, can result in the parasympathetic, and sympathetic nervous systems, so that it can increase the intensity of pain it feels (Pratiwi 2016).

Nonpharmacological pain management can increase satisfaction during labor because the patient can control his feelings and strength. Relaxation, breathing techniques, movement and positional changes, massage, hydrotherapy, heat/cold therapy, Auditory (mutual), guided imagery, acupressure, aromatherapy are some of the nonpharmacological techniques that can improve patient comfort during childbirth and have an effective influence on the labor experience (Simanullang 2020). According to research (Sukarta 2017), At Lawawoi Health Center, Wattang Pulu Subdistrict, Sidenreng Rappang Regency in 2016, stated that with the provision of effective breath relaxation techniques to reduce pain levels in inpartu patients when I was active because there was a significant difference between before and after the administration of breathing techniques. Siti Farida's 2015 research, At BPM Fajar Endrowati Boyolali, stated the breathing relaxation technique effects to reduce pain during the labor process Research (Sukarta 2017), he stated that the provision of breath relaxation techniques is effective to reduce the level of pain in inpartu patients when I active phase in Lawawoi Health Center Wattang Pulu District Sidrap. The purpose of this study was to find out the effect of respiratory relaxation techniques on pain adaptation in maternity mothers.

\section{Review of Literature}

Pain is an integral part of childbirth and childbirth (Wildan, Jamhariyah, and Purwaningrum 2012). Childbirth is a process of production of conception (fetus and uri), which can live from the inside of the uterus through the vagina to the outside world (Sayuti and Ulandari 2015). While according to (Triwidiyantari 2021), Childbirth is a series of physiological processes that end with the production of the results of conception by the mother. Physiological processes generally begin with contractions characterized by progressive changes in the cervix and ends with the birth of the placenta.

Labor pain is caused by straining the lower segments of the uterus and is associated with two different types of pain. First, the pain comes from the uterine muscle, at which time this muscle contracts the pain that arises is called visceral pain. While the second pain that arises at the close of birth is called somatic pain and is caused by stretching the structure of the lower birth canal due to a decrease in the bottom part of the fetus (Sulistiawati $\square$ 2020). Pain during labor is felt during the opening and gets worse when spending. In first-time mothers, the opening lasts about 13 hours, and when production is about $11 / 2$ hours. In women who have given birth when the opening lasts shorter, which is about 7 hours and when spending about 1/2 hour (Herinawati, Hindriati, and Novilda 2019).

\section{Research Methods}

This type of research is descriptively correlational, using the One Group PretestPostest approach. Location in RSU Royal Prima Jalan Ayahanda Number 68A, Sei Putih Tengah, Medan Petisah, North Sumatra, september - November 2020. The population in 
this study was all maternity mothers pervaginam at RSU Royal Prima. From the survey results, the data of the last 3 months, the average monthly number of maternity mothers pervaginam at Royal Prima Hospital is \pm 43 people.

Number of samples using the formula Slovin:

$$
n=\frac{N}{1+N e^{2}}
$$

$\mathrm{n}=43 / 1+43(0,01)^{2}$

$\mathrm{n}=30,06$ rounded to 30 responders, with a significance level of $\alpha=0.01$.

Selection of samples with non-probability sampling is consecutive sampling. Sample inclusion criteria, namely:

a. Pregnant women who are pregnant in the KIA room at RSU Royal Prima.

b. Vaginal delivery.

c. Vital signs (blood pressure, pulse, temperature and breathing) of stable patients.

d. Patients who are willing to be responders.

Sample exclusion criteria, namely:

a. Vital signs are unstable.

b. Patients experience a decrease in consciousness.

c. Mothers who get accelerated labor (SC, induction of labor).

d. Not willing to be a respondent.

Operational definitions in this study are as shown in the following table d. Not willing to be a respondent:

Table 1. Operational Definition

\begin{tabular}{|c|c|c|c|c|c|}
\hline Variable & $\begin{array}{c}\text { Operational } \\
\text { Definition }\end{array}$ & Parameter & $\begin{array}{c}\text { How to } \\
\text { Measure }\end{array}$ & $\begin{array}{l}\text { Data } \\
\text { Scale }\end{array}$ & Result \\
\hline \multicolumn{6}{|l|}{ Independent } \\
\hline $\begin{array}{l}\text { Breathing } \\
\text { Relaxation } \\
\text { Techniques }\end{array}$ & $\begin{array}{l}\text { A form of } \\
\text { nursing care, in } \\
\text { which case the } \\
\text { nurse teaches the } \\
\text { client how to } \\
\text { breathe, slow } \\
\text { breathing } \\
\text { (holding } \\
\text { inspiration to the } \\
\text { maximum) and } \\
\text { how to exhale } \\
\text { slowly. }\end{array}$ & $\begin{array}{l}\text { Respiratory } \\
\text { Relaxation } \\
\text { technique } \\
\text { procedure }\end{array}$ & $\begin{array}{l}\text { Respiratory } \\
\text { Relaxation } \\
\text { technique } \\
\text { procedure }\end{array}$ & Nominal & $\begin{array}{l}\text { 1.Can Do Well } \\
\text { 2.Unable to } \\
\text { perform well }\end{array}$ \\
\hline \multicolumn{6}{|l|}{ Dependen } \\
\hline Labor Pain & $\begin{array}{l}\text { The level of } \\
\text { pain at the time } \\
\text { of delivery is } \\
\text { expressed } \\
\text { verbally by } \\
\text { showing the } \\
\text { range of pain } \\
\text { scale } 0-10 \text {. }\end{array}$ & $\begin{array}{l}\text { Observati } \\
\text { on Sheet }\end{array}$ & $\begin{array}{l}\text { Intervention } \\
\text { group and the } \\
\text { control group } \\
\text { Asked } \\
\text { Describe the } \\
\text { taste Pain felt } \\
\text { with a scale of } \\
\text { intensity of } \\
\text { derritive pain, } \\
\text { Then show }\end{array}$ & Ordinal & $\begin{array}{l}\text { : No pain } \\
\text { : Mild pain } \\
\text { : Moderate pain } \\
\text { : Severe pain } \\
10 \quad: \text { Very } \\
\text { painful } \\
\text { heavy }\end{array}$ \\
\hline
\end{tabular}




\begin{tabular}{ll}
\hline & One of the \\
numbers on \\
pain scale \\
range \\
provided. \\
\hline
\end{tabular}

The data analysis used is, the normality test using the Shapiro Wilk test, because the number of samples $<50$. Bivariate analysis if the data is normally distributed using a $t-$ dependent test (paired t-test), while if the data is not distributed normally using the Wilcoxon Signed Rank Test, with the meaningful limit $<0.05$.

\section{Discussion}

\subsection{Results}

\section{a. Karateristik Respondents at Royal Prima Medan Hospital year 2020}

The characteristics of respondents are a picture of the diversity of respondents based on gender, age, education and occupation. Based on this characteristic is expected to provide a better and clearer description of the condition of the 100 respondents and their relationship to the problem and the purpose of the study.

Table 2. Overview of Research Respondents, based on Age, Education and Employment Status

\begin{tabular}{lccc}
\hline Characteristic & Category & Sum & Percentage \\
\hline \multirow{2}{*}{ Age } & $<25$ Year & 8 & $26,7 \%$ \\
& $>25$ Year & 22 & $73,3 \%$ \\
\hline \multirow{2}{*}{ Education } & SMP & 11 & $36,7 \%$ \\
& SMA & 7 & $23,3 \%$ \\
& Pendidikan Tinggi (D3, S1, & 12 & $40,0 \%$ \\
Employment & S2, S3) & 9 & $30 \%$ \\
Status & PNS & 7 & $23,3 \%$ \\
& Private & 14 & $46.7 \%$ \\
\hline
\end{tabular}

Source: Primary data, processed 2020.

Age reflects the physical condition of a person. In relation to the field of health, age can reflect the specific health care needs in a person. Based on Table 1. The largest number of respondents in the age of $>25$ years, which is as many as 22 patients. The level of education reflects the level of intellect of a person. Based on table 1. It is known that the largest number of respondents at the Higher Education Level is as many as 15 patients. Employment status reflects a person's income level. This condition often also reflects the selection of locations for health checks. Based on table 1. It is known that the largest number of respondents on employment status is self-employment which is as many as 20 patients.

\section{b. Maternity Mother Pain Level before Respiratory Relaxation Techniques at Royal Prima Medan Hospital in 2020}

The results of research on the level of maternal labor pain in the Kala I phase, before the respiratory relaxation technique. Labor pain is caused by a strain of the lower 
segment of the uterus. The intensity of pain is proportional to the strength of contractions and pressure that occurs, the pain increases when the cervix is fully dilated due to the baby's pressure on the pelvic structure followed by strain and tearing of the birth canal. Labor pain is unique and different in each individual because pain is not only associated with physical condition alone but also related to the psychological condition of the mother at the time of delivery. The level of pain can be seen on the scale of the intensity of descriptive pain, where $0=$ painless, $1-3=$ mild pain, $4-6=$ moderate pain, $7-9=$ severe pain, $10=$ very severe pain.

Table 2. Distribution of Frequency and Percentage of Pain Levels of Maternity Mothers Kala I, Before Breathing Relaxation Techniques At Royal Prima Medan Hospital in 2020

\begin{tabular}{llcc}
\hline No & Pain Level & Sum $(\mathbf{n})$ & Percentage \\
\hline 1 & Moderate Pain & $\mathbf{1 6}$ & $\mathbf{5 3 , 3}$ \\
\hline 2 & Severe Pain & $\mathbf{1 4}$ & $\mathbf{4 6 , 7}$ \\
\hline & Sum & $\mathbf{3 0}$ & $\mathbf{1 0 0}$
\end{tabular}

Based on table 2. It is known that before the respiratory relaxation technique, the majority of respondents felt more moderate pain as many as 16 people, while a minority of respondents experienced severe pain as many as 14 people.

\section{c. Respiratory Relaxation Techniques Performed on Maternity Mothers Kala I at Royal Prima Medan Hospital in 2020} mothers.

Respiratory Relaxation Techniques are very useful to help reduce pain in birthing

Table 3. Distribution of Frequency and Percentage of Respiratory Relaxation Techniques of Maternity Mothers Kala I at Royal Prima Medan Hospital in 2020

\begin{tabular}{llcc}
\hline No & Relaxation of Breathing & Sum (n) & Percentage \% \\
\hline 1 & Can Do Well & $\mathbf{1 7}$ & $\mathbf{5 6 , 7}$ \\
\hline 2 & Can't Do Well & $\mathbf{1 3}$ & $\mathbf{4 3 , 3}$ \\
\hline \multicolumn{2}{c}{ TOTAL } & $\mathbf{3 0}$ & $\mathbf{1 0 0}$
\end{tabular}

Based on table 3. It is known that the majority of respondents who can perform respiratory relaxation techniques well while the minority cannot do well.

\section{d. Pain Level of Maternity Mother Kala I after Respiratory Relaxation Technique At Royal Prima Medan Hospital in 2020}

Based on table 4. It is known that after the technique of relaxation of breathing, no pain as many as 7 people, moderate pain as many as 11 people, severe pain as many as 12 people. There is an effect after respiratory relapse, where after intervention, there is a decrease in the level of pain, where previously the level of pain is 0 , to 7 maternity mothers.

Table 4. Distribution of Frequency and Percentage of Pain Rate of Maternity Mothers When I after Respiratory Relaxation Techniques at Royal Prima Medan Hospital in 2020

\begin{tabular}{llcc}
\hline No & Pain Level & Sum $(\mathbf{n})$ & Percentage \\
\hline 1 & No pain & $\mathbf{7}$ & $\mathbf{2 3 , 3}$ \\
\hline 2 & Moderate Pain & $\mathbf{1 1}$ & $\mathbf{3 6 , 7}$ \\
\hline 3 & Severe Pain & $\mathbf{1 2}$ & $\mathbf{4 0 , 0}$ \\
\hline
\end{tabular}




\section{e. Pain Levels before and after Respiratory Relaxation Techniques in Maternity Mothers in Phase I At Royal Prima Medan Hospital in 2020}

Based on table 5. Showed that the average level of pain before the technique of relaxation of breathing mean score was 6.26 and after the technique of relaxation of breathing mean score 5.60 there was a difference of decrease of 0.66 . The minimum value of pain level in pre respiratory relaxation techniques is 4 and the maximum value is 9 , while in post respiratory relaxation techniques the minimum pain level is 2 and the maximum value is 8 .

Table 5. Pain Levels Before and After Respiratory Relaxation Techniques in Maternity Mothers in Phase I at Royal Prima Hospital

\begin{tabular}{|c|c|c|c|c|c|}
\hline No & Pain Level & Sum (n) & Mean & SD & Min Max \\
\hline 1 & $\begin{array}{l}\text { Pre-Breathing } \\
\text { Relaxation Techniques }\end{array}$ & 30 & 6,26 & $\mathbf{1 , 3 3 7}$ & 4-9 \\
\hline 2 & $\begin{array}{l}\text { Post- } \quad \text { Respiratory } \\
\text { Relaxation Techniques }\end{array}$ & 30 & 5,60 & 1,830 & $2-8$ \\
\hline
\end{tabular}

\section{f. Bivariate Analysis}

The data normality test uses Shapiro-Wilk, this is because the number of samples used is no more than 50 samples, and the ordinal scale.

Table 6. Shapiro Wilk's Normality Test

\begin{tabular}{lccc}
\hline & \multicolumn{3}{c}{ Shapiro Wilk } \\
\cline { 2 - 4 } & Statistic & df & Sig \\
\hline Pre-Relaxation & 0.637 & 30 & 0,000 \\
\hline Post-Relaxation & 0.794 & 30 & 0,000 \\
\hline
\end{tabular}

From table 6. Before the intervention of respiratory relaxation techniques obtained a value of Sig $0.000>0.05$ and after the intervention of respiratory relaxation techniques obtained a value of Sig $0.000>0.05$. Then the data is not distributed normally, then continued with the Wilcoxon Signed Rank Test statistical test.

Based on table 7. It is known that the change in pain level of wilcoxon test results at the time of the pre-test test the result of the mean value is 3,466 , at the time of the posttest test the mean value is 3,166 . So the result of the value $Z=-, 714$ then $p$ value as much as $0.007<0.05$ so that it is concluded ho rejected and Ha received, which means there is an effect of giving respiratory relaxation techniques to changes in pain in maternity mothers when I at RSU Royal Prima in 2020.

Table 7. Wilcoxon Signed Ranks Test Results Change in Pain Levels before and after Respiratory Relaxation Techniques in Maternity Mothers When I at Royal Prima Medan

Hospital in 2020

\begin{tabular}{llcccc}
\hline No & Pain Level & Sum $(\mathbf{n})$ & Mean & Z & p-value \\
\hline 1 & Pre-Relaxation of Breathing & $\mathbf{3 0}$ & $\mathbf{3 . 4 6 6}$ & \multirow{2}{*}{$\mathbf{2 . 7 1 4}^{\mathbf{b}}$} & $\mathbf{0 . 0 0 7}$ \\
\cline { 1 - 3 } 2 & Post- Relaxation of Breathing & $\mathbf{3 0}$ & $\mathbf{3 . 1 6 6}$ & & \\
\hline
\end{tabular}




\subsection{Discussion}

\section{a. Pain Level before Being Given Respiratory Relaxation Techniques in Maternity Mothers Kala I at Royal Prima Medan Hospital in 2020}

Pain is an integral part of childbirth and childbirth (Wildan et al. 2012). Childbirth is a process of production of conception (fetus and uri), which can live from the inside of the uterus through the vagina to the outside world (Sayuti and Ulandari 2015). While according to (Triwidiyantari 2021), Labor is a series of physiological processes that end with the production of conception by the mother. Pain is a source of frustration, both for clients and for health workers (Berkanis, Nubatonis, and Lastari 2020). Pain is a highly individualized and subjective experience that can affect everyone at any age. Pain can occur in children and adults. Causes of pain are the process of disease, injury, procedures, and surgical interventions (Kyle, T \& Carman 2015). Labor pain caused by strain of the lower segment of the uterus (Setianto 2017). The intensity of pain is proportional to the strength of contractions and pressure that occurs, the pain increases when the cervix is fully dilated due to the baby's pressure on the pelvic structure followed by strain and tearing of the birth canal. Labor pain is unique and different in each individual because pain is not only associated with physical condition alone, but also related to the psychological condition of the mother at the time of delivery.

Based on the results of a study of 30 respondents on the effect of giving Respiratory Relaxation Techniques to Birth mothers Kala I at Royal Prima Medan Hospital in 2020, before the respiratory relaxation technique, the majority of respondents felt more moderate pain while a minority of respondents experienced severe pain.

\section{b. Pain Level after Being Given Respiratory Relaxation Techniques in Maternity Mothers Kala I at Royal Prima Medan Hospital in 2020}

Childbirth is associated with two different types of pain. First the pain comes from the uterine muscle, when this muscle contracts the pain that arises, which is visceral pain. This pain cannot be determined exactly the location (Pain-Pointed). Visceral pain can also be felt in others who are not the origin of it called reffered pain. In labor, over-pain can be felt in people with lower back and sacrum. While the second pain arises at the time of approaching birth. Unlike visceral pain, this pain is localized in the vaginal, rectum and perinium areas around the anus. This type of pain is called somatic pain and is caused by stretching the lower birth canal structure due to a decrease in the bottom part of the fetus (Sulistiawati $\square$ 2020).

The sensation of pain is produced by a network of complex nerve fibers that produce the peripheral and central nervous systems. In labor pain, the autonomic nervous system and especially the sympathetic component play a role in sensation. Based on the results of a study of 30 respondents on Pain Levels After Being Given Respiratory Relaxation Techniques in Maternity Mothers Kala I At Royal Prima Medan Hospital in 2020, there were results of no pain as many as 7 people, moderate pain as many as 11 people, severe pain as many as 12 people.

Pain during labor is a normal thing to happen. Causes include physiological and psychological factors (Girsang 2017). During the time of 1 delivery, pain is caused by dilation of the cervix and lower segments of the uterus and corpus uteri distension. Pain during this time is caused by the strength of contractions and the pressure raised. The findings found that omnion fluid pressure is more than $15 \mathrm{mmHg}$ above the tone needed to stretch the lower segments of the uterus and cervix and thus produce pain (Magfuroh 2012). 


\section{c. Effect of Respiratory Relaxation Techniques On Pain Levels in Maternity Mothers When I at Royal Prima Medan Hospital in 2020}

The results of the study from the Wilxocon Rank Test showed $\rho$-value $=0.007<$ $=0.05$, this means that $\mathrm{H} 0$ was rejected and $\mathrm{Ha}$ accepted the effect of giving Respiratory Relaxation Techniques to pain changes in Birth mothers Kala I in patients in the kia room of RSU Royal Prima in 2020. Labor pain during time 1 is caused by uterine contractions delivered by sympathetic sarfa fibers and thoracic nerve fibers 11 and 12. pain caused by stretching the mouth of the uterus. Pain is spread through the nerves of the spinal medulla, thoracal 11 and 12 and lumbar 1. Pain that arises is felt as 10\% back pain, 20\% low back pain and most pain in the lower part of the abdomen $70 \%$ (Sukarta 2017). In accordance with the theory that pain at the opening is caused by the opening of the cervix for example stretching smooth muscles is enough stimulation to cause pain, there is a close relationship between the magnitude of the opening of the cervix and the intensity of pain (increasingly open the pain), there is a relationship between the tirnbulnya uterine contractions, pain is felt about 15-30 seconds after the start of uterine contractions (Sukarta 2017).

According to Rejeki (2014), Severe and prolonged labor pain can affect ventilation, metabolic circulation and uterine activity. Pain during labor can cause blood pressure to increase and the mother's concentration during labor becomes disturbed, not infrequently pregnancy brings "stress" or worry / anxiety that has an impact and influence on the physical and psychological, both on the mother and on the fetus it contains. For example, resulting in physical disability and deterioration of intelligence and mental emotional pain and excessive pain will cause anxiety. Excessive anxiety also adds to the pain. Nonpharmacological therapy is a therapy that is used without the use of drugs, but by providing various techniques that can at least slightly reduce pain when labor arrives. Some things that can be done are distraction, self-hypnosis, cutaneous stimulas, massase, warm and cold therapy, respiratory relaxation. Respiratory relaxation is a form of nursing care, in which case the nurse invites the client how to do breathing, slow breathing (holding inspiration to the maximum) and how to exhale slowly. In addition to lowering the intensity of pain, respiratory relaxation techniques can also improve pulmonary ventilation and increase blood oxygenation (Rosmiati 2021). According to the usefulness of respiratory relaxation techniques considered able to relieve pain, the process of taking slow breaths through the nose (holding inspiration to the maximum) and exhaling through the mouth slowly.

The results of this study are supported by the results of the study (Sukarta 2017), Who conducted research on the effect of respiratory relaxation on the level of inpartu maternal labor pain during the active phase, at Lawawoi Health Center, the results of the study as many as 18 respondents $(78.3 \%)$, moderate pain as many as 5 respondents $(21.7 \%)$ and severe pain as many as 0 respondents. From the results of the study, there was an influence from before being given treatment and after being given treatment had a significant change in pain in maternity mothers. With advice, it is expected that in the future midwives in puskesmas can facilitate maternity mothers with this breathing relaxation technique can reduce pain in childbirth, especially in the inpartu when I active phase.

The results of this study are almost the same as the results of research that has been done by (Lestari 2015), with the title The Effect of Breath Relaxation Technique On Pain Adaptation Response In Mother Inpartu Kala I Active Phase In BPM Midwife P Yogjakarta City results that the intensity of pain before being given the average respiratory relaxation technique experienced severe pain and was given the technique of flat respiratory relaxation experienced mild pain. The results of this study are also supported 
by research (Farida 2016), with the title Effectiveness of Deep Breath Relaxation Against Labor Pain When I At BPM Fajar Endrowati Boyolali with the result that the breathing relaxation technique is effective to reduce pain during the labor process. The main advantage, the breath relaxation technique gives a relaxed feeling in controlling breathing so that it can reduce pain. give a relaxed feeling in controlling breathing so as to reduce pain.

\section{Conclusion}

The level of pain before the respiratory relaxation technique the majority of respondents felt more moderate pain while the minority of respondents experienced severe pain. The level of pain after the relaxation technique of breathing, no pain as many as 7 people, moderate pain as many as 11 people, severe pain as many as 12 people. There is an effect of giving respiratory relaxation techniques to changes in pain in maternity mothers when I at RSU Royal Prima in 2020, with a p-value of $0.007<0.05$.

\section{References}

Aeni, Nurul. 2011. "Risk Factors of Maternal Mortality." Jurnal Kesehatan Masyarakat Nasional Vol 7 No.(26):453-59.

Berkanis, Nubatonis, and Lastari. 2020. "Pengaruh Mobilisasi Dini Terhadap Intensitas Nyeri Pada Pasien." CHM-K Applied Scientifics Journal 3(1):6-13.

Farida, Siti. 2016. "Efektivitas Relaksasi Nafas Dalam Terhadap Nyeri Persalinan Kala I

Di Bpm Fajar Endrowati Boyolali." Maternity: Jurnal Kebidanan Dan Ilmu Kesehatan 3(November):31-48.

Girsang, Ivo Elkania. 2017. "Asuhan Keperawatan Pada Ny.T Dengan Prioritas Masalah

Kebutuhan Dasar Gangguan Rasa Nyaman: Nyeri Pada Ibu Melahirkan Di

Kelurahan Sari Rejo Kecamatan Medan Polonia.” Repositori Universitas Sumatera Utara 1(1):7-33.

Herinawati, Herinawati, Titik Hindriati, and Astrid Novilda. 2019. "Pengaruh Effleurage Massage Terhadap Nyeri Persalinan Kala I Fase Aktif Di Praktik Mandiri Bidan Nuriman Rafida Dan Praktik Mandiri Bidan Latifah Kota Jambi Tahun 2019.” Jurnal Ilmiah Universitas Batanghari Jambi 19(3):590.

Kyle, T \& Carman, S. 2015. Buku Praktik Keperawatan Pediatri. Jakarta: EGC.

Lestari, Winny Putri. 2015. "Pengaruh Teknik Relaksasi Nafas Dalam Terhadap Respon Adaptasi Nyeri Pada Ibu Inpartu Kala I Fase Aktif Di BPM Bidan P Kota Yogyakarta." 3:2015.

Magfuroh, Annisa. 2012. "Faktor-Faktor Yang Berhubungan Dengan Nyeri Persalinan Kala 1 Fase Aktif Di Ruang Bersalin Rumah Sakit Umum Kabupaten Tangerang.” $1-74$.

Pratiwi, Dita. 2016. "Pemberian Teknik Relaksai Nafas Dalam Terhadap Adaptasi Nyeri Persalinan Ibu Bersalin Kala I Fase Aktif Pada Asuhan Keperawatan Ny.W Di Puskesmas Sibela Mojosongo.” Skripsi 11-75.

Rejeki, Sri. 2013. "Tingkat Nyeri Pinggang Kala i Persalinan Melalui Teknik.” Jurnal Keperawatan Maternitas 1(2):124-33.

Rejeki, Sri. 2014. "Tingkat Nyeri Dan Prostaglandin-E2 Pada Ibu Inpartu Kala I Dengan Tindakan Counter-Pressure.” Jurnal Ners Vol. 9(1).

Respati, Supriyadi Hari, Sri Sulistyowati, and Ronald Nababan. 2019. "Analisis Faktor Determinan Kematian Ibu Di Kabupaten Sukoharjo Jawa Tengah Indonesia.” Jurnal 
Kesehatan Reproduksi 6(2):52.

Rosmiati, Yati. 2021. "The Effect of Breath Relaxation Techniques on the Reduction of Pain Scale in Post Operating Laparatomic Patients in Space Al-Insan Room Hospital Linggau Lubuk City." ANJANI Journal: Health Sciences Study Rosmiati, Y 1(1):32-40.

Sayuti, and Sripina Ulandari. 2015. "Pengaruh Pendampingan Suami, Saudara/Ibu, Dan Teman Terhadap Kelancaran Proses Persalinan Di Pujon Kabupaten Malang." 3(2):30-38.

Setianto, Rosalina. 2017. "Pengaruh Massage Effleurage Terhadap Pengurangan Rasa Nyeri Pada Persalinan Kala I Fase Aktif Di Wilayah Kerja Puskesmas Kemalang." Journal Center of Research Publication in Midwifery and Nursing 1(2):55-61.

Simanullang, Ester. 2020. "Pengaruh Therapy Musik Religi Islam Terhadap Intensitas Nyeri Bersalin Dan Penurunan Kecemasan Persalinan Pada Ibu Inpartu Di Puskesmas Sawit Seberang Kecamatan Sawit Seberang Kabupaten Langkat." Dinamika Kesehatan Jurnal Kebidanan Dan Keperawatan 11(2):518-26.

Sukarta, Asmah. 2017. "Pengaruh Teknik Relaksasi Nafas Terhadap Tingkat Nyeri Persalinan Ibu Inpartu Kala Fase Aktif.” Jurnal Ilmiah Kesehatan Iqra IV:39-45.

Sulistiawati $\square$, Rini. 2020. "Fase Aktif Persalinan Normal Di Puskesmas Sungai Durian Kabupaten Kubu Raya.” Jurnal Kebidanan Khatulistiwa 6:35-42.

Sumarni, Sri, and Zakiyah Yasin. 2016. "Pengaruh Intervensi Akupresur Dalam Proses Distraksi Pasien Intranatal Untuk Menurunkan Nyeri Persalinan Di Wilayah Kerja Pilindes Sriwahyuni Saronggi Sumenep.” Jurnal Kesehatan 6 No 1:35-42.

Triwidiyantari, Dyah. 2021. "Peran IMD Terhadap Kala III Persalinan.” XV:169-73.

Widiawati, Ida, and Titi Legiati. 2017. "Mengenal Nyeri Persalinan Pada Primipara Dan Multipara." Jurnal Bimtas 2(1):42-48.

Wildan, Moh, Jamhariyah, and Yuniasih Purwaningrum. 2012. "Pengaruh Teknik Relaksasi Terhadap Adaptasi Nyeri Persalinan Ibu Bersalin Kala I Fase Aktif Di BPS Wilayah Puskesmas Patrang Kabupaten Jember Tahun 2012.” Jurnal IKESMA 9(1):65-73. 